\title{
Journal of Young Pharmacists - Fact sheet
}

\section{Subramani Parasuraman}

Editor-in-Chief, Journal of Young Pharmacist (JYP)

Correspondence

Dr. Subramani Parasuraman, Editor-in-Chief, Journal of Young Pharmacist (JYP)

Email: jypeditor@gmail.com

DOI: 10.5530/jyp.2018.10.56

Dear authors, reviewers and readers

Greetings form Editor-in-Chief

I would like to thank all the authors, researchers, scientist, readers, editorial board members and publisher for constant support for past nine years. With your support, currently Journal of Young Pharmacists (JYP) publishing decennial issue. In past years JYP contributed significantly to the science and made available the authors manuscript in global platform. Journal is licensed under a Creative Commons Attribution 4.0 (CC BY 4.0) International License which allows others to remix, tweak, and build upon the work non-commercially, as long as the author is credited and the new creations are licensed under the identical terms.

At this point time, I would like to present the 'Fact Sheet' on author submissions. The author submission will be checked for plagiarism and if any submissions has similarity index $>20 \%$, the submission will be returned to author. If author submission has similarity index $<20 \%$, that will be assigned to editor to executive internal/ external review process.

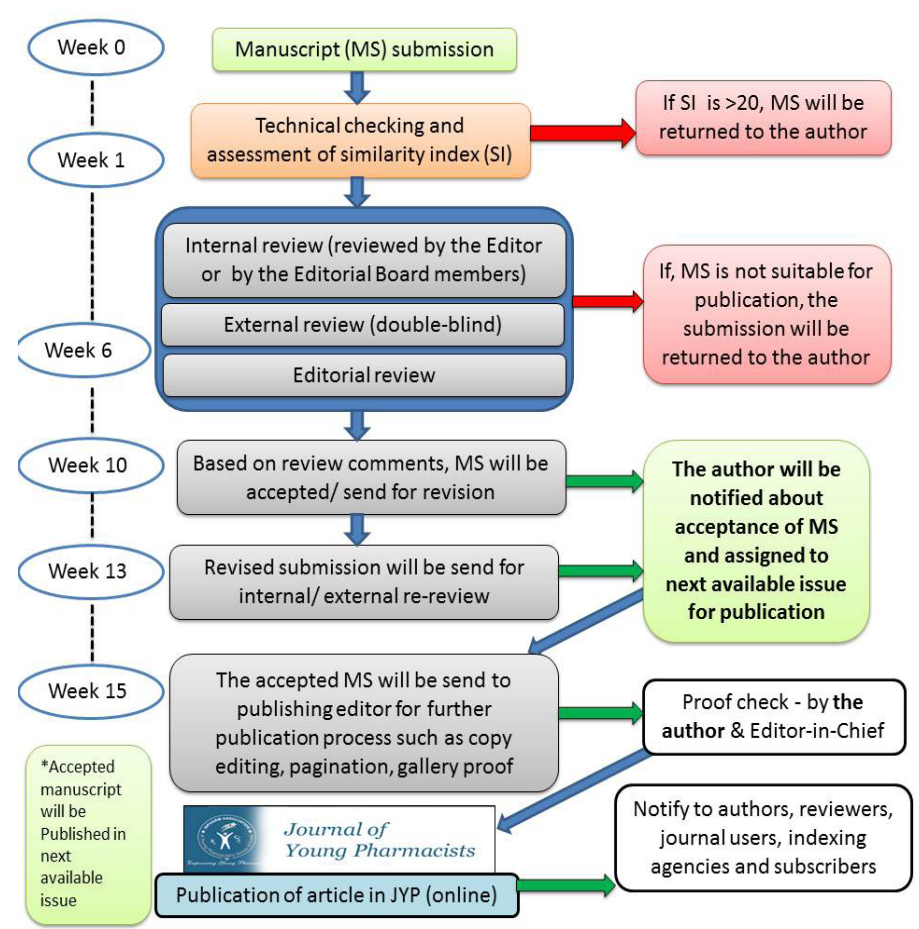

Figure 1: Editorial office workflow.
JYP uses double blind peer review system to ensure the scientific quality of author's submission. JYP editorial office workflow is summarized in Figure 1. Normally, JYP will take three to six weeks to complete the review (both internal and external review) process and the accepted manuscript will be assigned for publication in next available issue. The mean acceptance rate of author submissions to JYP (vol. 1 to 9 ) is $41 \%$ and frequency of acceptance rate per year is presented in Figure 2.

I would like to acknowledge the contributions of the editorial board members and the reviewers for their significance contributions to make decisions on author submissions prior to the publication. I also would like to acknowledge the contributions of founding editor, previous editor and editorial board members of JYP, web admin., Medknow Publications and EManuscript Services for their never-ending support.

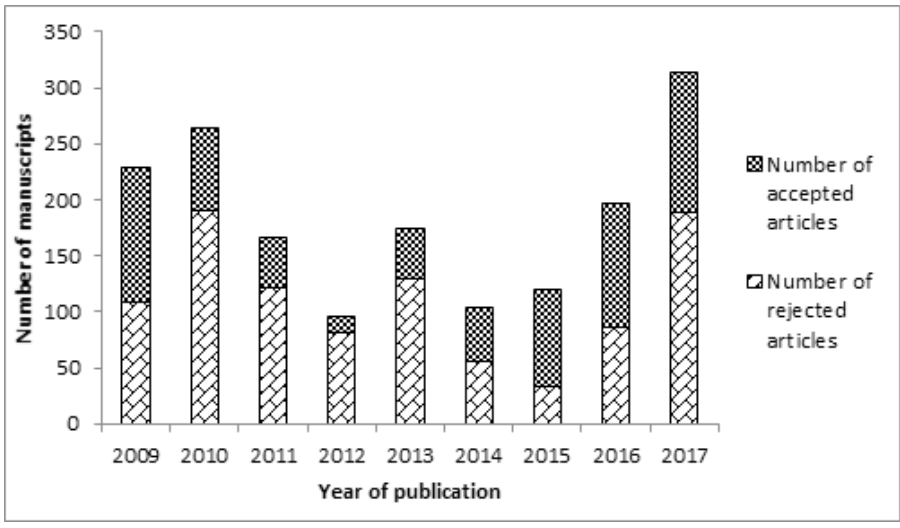

Figure 2: Frequency of manuscripts accepted by JYP during 2009-2017.

This is an open access article distributed under the terms of the Creative Commons Attribution-NonCommercial-ShareAlike 4.0 License, which allows others to remix, tweak, and build upon the work non-commercially, as long as the author is credited and the new creations are licensed under the identical terms. 